Do tekstu Ewangelii Judasza W. Myszor dołączył trzy fragmenty z pism herezjologicznych w wersji łacińsko-polskiej (ss. 64-87), w których znajdują się odniesienia do Ewangelii Judasza (Ireneusz Adversus haereses I 29-31 i II 20, 2 i 4-5 i Pseudo-Tertulian Adversus omnes haereses 2, 5-9) oraz podstawową bibliografię (ss. 88-90). Całość opatrzył trzema rodzajami indeksów: rzeczowym, cytowanych źródeł i cytowanych autorów nowożytnych.

Podkreślić należy, iż przekład krytycznego wydania Ewangelii Judasza przez W. Myszora jest jednym z pierwszych na świecie. Polski uczony przedstawił we „Wstępie” oryginalną charakterystykę teologicznego systemu utworu, popartą wieloletnimi badaniami nad tekstami gnostyckimi, w tym setiańskimi (których większość przetłumaczył). Niezwykle cenne dla dalszych badań nad Ewangelia Judasza są dokonane przez niego rekonstrukcje tekstu. W publikacji znajduje się bardzo mało błędów redakcyjnych. Należą do nich m.in. nieliczne literówki, np. w wyrażeniu пшнре м̄пемNoүте (,syn naszego Boga”)

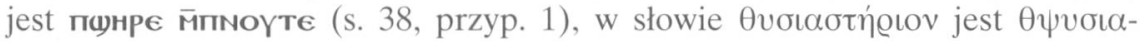
otท́oı (s. 42). Ponadto w wersji „B” część dziewiątą oznaczono numerem 10 (s. 61), a dziesiątą numerem 11 (s. 63). Szkoda jedynie, że tekst Ewangelii Judasza nie mógł być wydany w wersji dwujęzycznej: koptyjskiej i polskiej.

Anna Z. Zmorzanka - Lublin, KUL

\title{
James M. ROBINSON, Tajemnica Judasza: historia niezrozumianego ucznia i jego zaginionej ewangelii, thum. Jakub Slawik, Warszawa 2006, Nadir Media Lazar, ss. 248.
}

Odnalezienie w latach osiemdziesiątych XX w. zaginionej gnostyckiej Ewangelii Judasza (ed. R. Kasser [et al.], Washington 2006) jeszcze przed oficjalnym wydaniem jej tekstu, przyczyniło się do renesansu badań nad postacią Judasza oraz do spekulacji na temat przypisywanego mu pisma. Do tego nurtu zaliczyć można książkę Jamesa M. Robinsona, która ukazała się tuż przed publikacją tej ewangelii: The secret of Judas: the story of the misunderstood disciple and his lost Gospel (New York - San Francisco 2006). Zamiarem autora, emerytowanego profesora Uniwersytetu w Claremont (Claremont Graduate University) i założyciela Instytutu Badań nad Antykiem i Chrześcijaństwem (Institute for Antiquity and Christianity), znanego badacza gnostycyzmu oraz cenionego wydawcy tekstów gnostyckich z Nag Hammadi (m.in. The Nag Hammadi Library in English, Leiden 1977; wyd. $4^{\text {th }}$ ed. 1996), było jak sam pisze - przedstawienie szerszemu odbiorcy (co zakłada formę popularną) kontrowersji, jakie pojawiły się wokół postaci Judasza. W Stanach Zjednoczonych książka otrzymała skrajne oceny: od bardzo pozytywnych do zdecydowanie negatywnych (recenzje dostępne na stronie: www.amazon.com, 
20 X 2007). J.M. Robinsonowi zarzucano m.in. to, że podjął temat, nie znając jeszcze treści Ewangelii (G. Brown). Znał on jednak jej końcowy fragment, obejmujący wiersze 58, 19-28 (wraz z kolofonem), co stworzyło właściwą perspektywę dla podjętych rozważań. Publikacja od razu wzbudziła zainteresowanie wydawnictw zagranicznych, o czym świadczy fakt, że jeszcze w tym samym roku wydano jej dwa przekłady: francuski - Les secrets de Judas: l'histoire du disciple incompris et de son évangile (Paris 2006) i polski - Tajemnica Judasza: historia niezrozumiatego ucznia i jego zaginionej ewangelii (Warszawa 2006).

Polski wydawca zadbał, by książka posiadała odpowiednią otoczkę naukową. Przekładu na język polski dokonał bowiem Jakub Slawik (teolog protestancki, adiunkt w Katedrze Wiedzy Starotestamentowej i Języka Hebrajskiego w ChAT), „Wstęp” (ss. 7-32) napisał ks. prof. Wacław Hryniewicz (KUL), a nad całością czuwał prof. Janusz T. Maciuszko (ChAT) jako redaktor merytoryczny. Redaktorzy zaopatrzyli tekst w przypisy, w których podali m.in. dokładne opisy bibliograficzne cytowanych źródeł i informacje na temat polskiej literatury (np. przekładów tekstów gnostyckich i apokryfów) oraz „Glossariusz" (ss. 247-248) wyjaśniający podstawowe pojęcia (13 haseł). Usunęli natomiast obszerną bibliografię, którą podał sam autor (wspomina o niej w „Przedmowie”, s. 36). Na uwagę zasługuje „Wstęp” W. Hryniewicza (autora komentarza do polskiego wydania Ewangelii Judasza, zamieszczonego w dodatku do „Gazety Wyborczej”: Wydanie specjalne nr 16/ 677, 18 IV 2006, ss. 1-7: Ewangelia Judasza. Pierwsze polskie tlumaczenie kontrowersyjnego apokryfu z komentarzem J. Turnaua, ks. W. Hryniewicza i prof. Z. Mikołejki; tamże ss. 8-10: wywiad K. Wiśniewskiej z ks. prof. W. Hryniewiczem pt. Judasz, przyjaciel Jezusa? oraz artykuł Z. Mikołejki, s. 11: Wyzwanie wiary), w którym w sposób przystępny przedstawiona została treść Ewangelii; podkreślić należy, iż W. Hryniewicz słusznie wskazał na żydowskie korzenie pisma, zauważając, iż prezentowane w nim poglądy są ,interpretacją niektórych koncepcji judaizmu (m.in. dotyczących Pokolenia Seta) za pomocą idei platońskich" (s. 10). Jego zdaniem, publikacja Robinsona pozwala przede wszystkim spojrzeć ,,z większym zrozumieniem” na postać pseudoepigraficznego autora.

W książce wyodrębnić można dwie części, nie wyróżnione formalnie, ale różne na tyle, że mogłyby zostać wydane osobno. Pierwszą tworzą trzy rozdziały: „Judasz z Nowego Testamentu” (ss. 39-75), „Historyczny Judasz” (ss. 77-98), „Judasz w świetle gnozy” (ss. 99-137), drugą zaś stanowią kolejne trzy: „«Ewangelia Judasza» ponownie ujrzała światło dzienne w Genewie” (ss. 139-175), „Handel «Ewangelią Judasza»” (ss. 177-208), „Publikacja i znaczenie «Ewangelii Judasza»" (ss. 209-237).

W trzech pierwszych rozdziałach autor przedstawił charakterystykę Judasza w aspektach: biblijnym, historycznym i gnostyckim. Przewodnim motywem stało się pytanie: czy Judasz był zdrajcą, czy też wypełnił jedynie testamentowe proroctwo, przyśpieszając „Boży plan wobec Jezusa” (s. 39). Robinson, zgod- 
nie z panującą od pewnego czasu wśród teologów (m.in. W. Klassen, J. Cardonnel) tendencją, stara się bronić Judasza, zmieniając jego wizerunek. W tym celu odwołuje się do argumentu biblijnego i historycznego. Stwierdza zatem, iz przekaz kanoniczny nie był (poza Ewangelia Jana) dla Judasza tak niekorzystny (np. Judasz na tle innych uczniów, stosunek Jezusa do Judasza), jak przekazy późniejsze. Analizując centralną scenę w „wątku Judasza”, stwierdza za Klassenem (Judas: Betrayer or Friend of Jesus, Minneapolis 1996), iż użyty przez Mateusza (Mt 26, 25; 27, 4) i Łukasza (Ek 22, 21 - 22, 48) czasownik $\pi \alpha \varrho \alpha \delta i \delta \omega \mu$ (przekazywać, wydawać) oznaczał działanie, które w ówczesnym kontekście historycznym było „odpowiednim sposobem postępowania w świecie żydowskim" (s. 90). Z kolei wprowadzając w klimat gnostyckiego myślenia (idea ukrytego Boga przeciwstawionego Stwórcy świata, idea wybrania - ss. 108-113), Autor uzasadnia cześć, jaką gnostycy mieli dla Judasza oraz fakt przypisania mu Ewangelii; w tym kontekście jawi się on jako członek wybranego plemienia gnostyków, apostoł chrześcijaństwa ezoterycznego.

Trzy ostatnie rozdziały Robinson poświęcił dziejom Ewangelii Judasza od odkrycia kodeksu, zawierającego tekst, do jej wydania. Autor przedstawił w nich archiwalne już dziś materiały (najstarsze pochodzą z 1983 r.): fragmenty listów, raporty naukowców, fragmenty komunikatów i wywiadów prasowych, z których odtwarza kolejne etapy działań, by pozyskać kodeks do handlarzy. Materiały te dają również pewien pogląd na pracę specjalistów (papirologów, paleografów, koptologów), stawiających pierwsze pytania i hipotezy na temat znaleziska. Jedno z takich pytań dotyczyło pochodzenia kodeksu. R. Pearse, G. Quispel i H. van Oort, nie wykluczyli, iż stanowi on fragment zbioru z Nag Hammadi (ss. 158, 160, 161, 162), odłączony od całego korpusu w trakcie transportu (na możliwość taką wskazuje raport Robinsona z 1979 r.: The discovery of the Nag Hammadi Codices, „Biblical Archeologist” 42:1979, z. 4, 206-224, cyt. na ss. 156-157). Sam Autor nie podziela tej opinii; według niego nie została ona poparta dostatecznymi badaniami: m.in. analizą cech fizycznych kodeksu (pisma, technologii wytwarzania składek i okładek skórzanych) oraz kartonażu (czyli kawałków papirusów, często zapisanych, użytych do utwardzenia grzbietu). Interesujący wydaje się również fakt, iż pierwotnie - jak podaje Robinson - Ewangelia Judasza została powiązana z innym pseudoepigraficznym autorem - Tomaszem Judą Dydymosem. Z nim bowiem (w 1983 r.) skojarzył St. Emmel imię ıү $\mathbf{\Delta x c}$ umieszczone w kolofonie pisma (ss. 150, 152 -

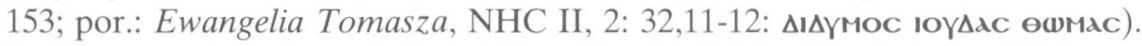
Robinson przypomina też, iż on i Emmel ogłosili jej odkrycie już w 1984 r. na III Międzynarodowym Kongresie Koptologicznym w Warszawie, identyfikując ją wówczas jako „dialog Jezusa z jego uczniami” (s. 164).

Książka Robinsona, pomimo cennych informacji zawartych w cz. II, które mogą zainteresować nawet specjalistów, sprawia wrażenie powierzchownej: np. w argumentacji biblijno-historycznej (dwa pierwsze rozdziały) autor nie 
powinien opierać się jedynie na słownikowym znaczeniu słowa $\pi \alpha \varrho \alpha \delta i \delta \omega \mu$, z pominięciem pełnego kontekstu jego użycia; być może dokładniejsza analiza kontekstu wskazałaby, iż czasownik ten będzie się kojarzył raczej ze zdradą, niż procedurę wydania (przekazania) sądowi. Z kolei w rozdziale trzecim: „Judasz w świetle gnozy” Autor pominął lub potraktował marginalnie kilka kwestii istotnych. Po pierwsze, nie rozwinął dostatecznie zagadnienia gnostyckiego antyjudaizmu, które powinno stanowić punkt wyjścia dla rozważań o ,gnostyckim” Judaszu. Po drugie, nie dość wyraźnie podkreślił, iż wątek Judasza pojawia się w kontekście tylko jednego gnostyckiego odłamu, co pokazują cytaty z Ireneusza (Adversus haereses I 31, 1), czy Epifaniusza (Panarion 37, 3). Po trzecie: nie skomentował wątku (należącego do gnostyckiej soteriologii) o Judaszu przyśpieszającym zbawienie, przytoczył jedynie (bez komentarza) wypowiedź Epifaniusza na ten temat (Panarion, 37, 4-5), pominął natomiast wypowiedź Pseudo-Tertuliana z Adversus omnes haereses (2), która ponadto sugeruje istnienie kultu. Po czwarte, nie uwzględnił fragmentu muzułmańskiego apokryfu Ewangelia Barnaby przedstawiającego krzyżowanie Judasza zamiast Jezusa (zob. M. Starowieyski, Judasz, historia, legenda, mity, Poznań 2006, ss. 55-62); wątek pozornej śmierci Jezusa (związany z doketyzmem) w chrystologii gnostyckiej odgrywał bowiem istotną rolę (wg karpokracjanów Jezusa zastąpił Szymon Cyrenejczyk). Ponadto kompozycja tego rozdziału wydaje się nie przemyślana: dziwi np. podrozdział „Jak robi się papirusową książkę" (przedstawia technikę robienia ksiąg papirusowych). Zarzut, jaki skierować można pod adresem trzech ostatnich rozdziałów, dotyczy niedostatecznej selekcji źródeł, z których Autor korzystał. W swojej relacji, obok dokumentów wartościowych (raporty, listy), bezkrytycznie cytuje sensacyjne informacje prasowe, co wpływa niekorzystnie na wartość przekazu.

Anna Z. Zmorzanka - Lublin, KUL

\begin{abstract}
Ks. Krzysztof BARDSKI, Stowo oczyma gołębicy. Metodologia symbolicznoalegorycznej interpretacji Biblii oraz jej teologiczne i duszpasterskie zastosowanie, Warszawa 2006, Wydawnictwo Archidiecezji Warszawskiej, ss. 298.
\end{abstract}

Ks. dr hab. Krzysztof Bardski, wykładowca na Uniwersytecie Kardynała Stefana Wyszyńskiego i Papieskim Wydziale Teologicznym w Warszawie, reprezentuje należący jeszcze do rzadkości w polskiej biblistyce nurt badań zmierzający do umiejętnego - bardzo kompetentnego, unikającego zbytniego apologetyzmu, ale równocześnie zaangażowanego - ukazania nieprzemijających walorów alegorycznej egzegezy patrystycznej i średniowiecznej oraz wyjaśnienia kierujących nią zasad. Autor zaznacza we wprowadzeniu, że „praca ta 